\title{
Arthroscopic Treatment of Scaphoid Pseudoarthrosis without Bone Graft: Is it Really Feasible?
}

\section{Tratamiento artroscópico de la seudoartrosis de escafoides sin injerto óseo: ¿Es realmente factible?}

\author{
Martin F. Caloia ${ }^{1}$ Diego González Scotti ${ }^{2}$ Diego L. Fernández ${ }^{3}$ \\ ${ }^{1}$ Head of Section of Upper Member Surgery, Orthopedics and \\ Traumatology, Hospital Universitario Austral, Facultad de medina \\ Universidad Austral, Buenos Aires, Argentina \\ 2 Upper Limb Surgery Section, Orthopedics and Traumatology, \\ Hospital Universitario Austral, Buenos Aires, Argentina \\ ${ }^{3}$ Universidad de Berna, Berna, Switzerland \\ Address for correspondence Martin F. Caloia, Miembro Fundador-Jefe \\ Sección Hospital Universitario Austral, Pilar, Libertador 3552 8D, \\ Palermo Nuevo, Capital Federal, Buenos Aires, Argentina \\ (e-mail: mcaloia@intramed.net). \\ Rev Iberam Cir Mano 2020;48:31-41.
}

\begin{abstract}
Keywords

- scaphoid pseudoarthrosis

- wrist arthroscopy

- without bone graft

- metaphyseal decompression

Introduction The current management of scaphoid pseudoarthrosis remains controversial, with a failure rate of up to $40 \%$ and no "gold standard" treatment. Based on innovative concepts about the osteogenic potential of cells from scaphoid pseudoarthrosis, encouraging results from increased vascularization by radial and ulnar metaphyseal decompression for Kienböck disease therapy and the advantages of minimal surgical trauma provided by percutaneous and arthroscopic techniques, we analyzed prospective outcomes from scaphoid pseudoarthrosis arthroscopic treatment with no bone graft (ATSPsWBG) to determine its feasibility.

Materials and Methods Eighty-four non-union scaphoid prospectively treated for ATSPSWBG were evaluated. Patients had, on average, 32.42 years old. The dominant limb was affected in $77.5 \%$ of the cases (65 patients). Mean time from injury to surgical intervention was 20.57 months. Twenty-three fractures were initially treated conservatively with orthopedic cast for an average period of 6.3 weeks, including 17 already immobilized at the time of the visit. All patients were grouped according to the classification proposed by the authors (MC \& DF), which is based on perioperative studies.

Results Bone consolidation was obtained in 77 cases (91.66\%) and documented by computed tomography (CT) scans. Seven cases presented no bone consolidation 9 months after the procedure, and four cases required a new surgery. In cystic pseudoarthrosis, the bone defect was filled with a new bone growth even when the cyst exceeded $10 \mathrm{~mm}$. Single photon emission computerized tomography (SPECT) scans revealed an unique pattern, documenting the biological effect of metaphyseal decompression, which is characterized by increased nonspecific irrigation of the radial column. Average postoperative pain assessed using the visual analog scale was 1.04 (range, 0 to 2). Average postoperative functional range was $65.3^{\circ}$ for extension (range,
\end{abstract}

received

March 29, 2020

accepted

April 3, 2020
DOI https://doi.org/

10.1055/s-0040-1712089. ISSN 1698-8396.
Copyright $\odot 2020$ Thieme Revinter

Publicações Ltda, Rio de Janeiro, Brazil
License terms

(c) (i) $\ominus$ (\$) 


\section{Resumen}

\section{Palabras clave}

- seudoartrosis escafoides

- artroscopía de muñeca

- sin injerto óseo

- descompresión metafisaria $46^{\circ}$ to $88^{\circ}$ ), $69.2^{\circ}$ for flexion (range, $55^{\circ}$ to $88^{\circ}$ ), $10.7^{\circ}$ for radial deviation (range, $5^{\circ}$ to $20^{\circ}$ ) and $26^{\circ}$ for ulnar deviation (range, $20^{\circ}$ to $37^{\circ}$ ). Average Mayo Clinic score was 95. Conclusion The arthroscopic treatment of scaphoid pseudoarthrosis with no bone graft is recommended in young to middle-aged, non-smokers patients with no scaphoid consolidation, with hemorrhagic peteqchiae (arthroscopic Green's Sign) at the arthroscopic evaluation and in which a CT scan excluded the presence of an excessive sclerosis focus or revealed a very small proximal bone fragment not suitable for screw placement for stable internal fixation. Our experience proved that this is a reproducible and feasible technique.

Level of Evidence IV

Introducción En la actualidad, el manejo de la seudoartrosis del escafoides sigue siendo controvertido, con una tasa de fallas que puede llegar hasta el $40 \%$ y con ausencia de un "patrón de oro" de tratamiento. Tomando los novedosos conceptos sobre el potencial osteogénico de las células encontradas en la seudoartrosis de escafoides de años de evolución, los alentadores resultados por los efectos del aumento de la vascularización por la descompresión metafisaria del radio y cúbito para el tratamiento de la enfermedad de Kienböck y las ventajas del mínimo trauma quirúrgico de las técnicas percutáneas y artroscópicas, es que planteamos la hipótesis de realizar en forma prospectiva el Tratamiento Artroscópico de la Seudoartrosis de Escafoides sin Injerto Óseo. [T.A.S.E s. I.O] y evaluar si era una técnica factible.

Material y Método Se evaluaron 84 no uniones de escafoides tratados en forma prospectiva mediante T.A.S.E s. I. La edad promedio fue de 32.42 años. El miembro dominante se vio afectado en el 77,5 . \% de los casos (65 pacientes). El tiempo promedio desde ocurrida la lesión hasta la intervención quirúrgica, fue de 20,57 meses. Veinte tres de las fracturas fueron tratadas inicialmente en forma conservadora con yeso con un promedio de 6,3 semanas, 17 de las cuales vinieron con la inmovilización al momento de la consulta. Acorde a los estudios peri-operatorios, todos los pacientes fueron agrupados según la clasificación propuesta por los autores (MC \& DF).

Resultados Se obtuvo la consolidación ósea en 77 casos (91,66\%), la cual fue documentada mediante T.A.C. En 7 casos no se alcanzó, luego de 9 meses de evolución, y 4 requirieron un nuevo procedimiento quirúrgico. En las seudoartrosis quísticas, el defecto óseo fue rellenado con crecimiento óseo nuevo, aún en aquellos casos en que el quiste excedía los $10 \mathrm{~mm}$. El SPECT demostró en los casos realizados, un patrón singular documentando en cierta medida el efecto biológico de la descompresión metafisaria caracterizada por un aumento de la irrigación inespecífica sobre la columna radial. La escala visual analógica mostró un dolor postoperatorio promedio de 1,04 ( 0 a 2). El rango funcional promedio postoperatorio fue de: extensión $65,3^{\circ}$ (rango $46^{\circ}$ a $88^{\circ}$ ), flexión de $69,2^{\circ}$ (rango $55^{\circ}$ a $88^{\circ}$ ), desviación radial $10,7^{\circ}$ (rango 5 a $20^{\circ}$ ) y desviación cubital $26^{\circ}$ (rango 20 a $37^{\circ}$ ). El promedio del escore de la Clínica Mayo arrojó una puntuación de $95 \pm$

Conclusión Se recomienda el Tratamiento Artroscópico de la Seudoartrosis del Escafoides Sin Injerto Óseo como abordaje terapéutico para aquellos pacientes, jóvenes o de mediana edad, no fumadores, con falta de consolidación del escafoides, en la que previamente se ha excluido mediante la T.A.C, una excesiva esclerosis del foco o un fragmento proximal muy pequeño con una trama ósea inadecuada para la colocación de un tornillo que asegure una fijación interna estable y con ausencia de petequiado hemorrágico en la evaluación artroscópica. Nuestra experiencia demostró ser una técnica reproducible y factible.

Nivel de evidencia IV 


\section{Introduction}

Since the initial description by Causin and Destot in 1895 , scaphoid fractures are among the most frequent hand fractures, accounting for $70 \%$ of all carpal fractures and 2 to $7 \%$ of all fractures. ${ }^{1}$ More than $80 \%$ of patients with a scaphoid fracture are active young men between 20 and 30 years old ${ }^{2}$ and high functional demand; as such, this condition has an important socioeconomic repercussion., 3

Early diagnosis and an adequate initial treatment often result in fracture healing with no complications. ${ }^{3,5}$ However, delayed fracture detection, lack of adequate early immobilization, proximal pole fractures, fractures displaced by more than $1 \mathrm{~mm}^{6}$ and/or associated carpal instability characteristically have reduced consolidation capacity. ${ }^{7,8}$ In addition, the poor vascularization pattern ${ }^{6,9}$ and the complex threedimensional articular shape of the fracture ${ }^{10,11}$ can add to the delayed consolidation or result in pseudoarthrosis (which can occur in up to $75 \%$ of the cases when the line is located in the proximal pole) and/or avascular necrosis. As such, scaphoid fractures have the highest incidence rate of pseudoarthrosis in the human body, with an average value of $55 \% .{ }^{11-13}$ On the other hand, scaphoid ligament attachments represent a critical link in wrist kinematics. ${ }^{14,15}$ Therefore, the preservation of its anatomy and vascularity are key requirements for normal hand and wrist function.

Despite the large number of published reports, the management of scaphoid pseudoarthrosis continues to be controversial, with a failure rate around 25 to $40 \%$, and no "gold standard" treatment. ${ }^{16}$ As such, this is a real challenge, even for experienced surgeons. These controversies arise from the lack of consensus on how to definite avascular necrosis, delayed consolidation, non-union, pseudoarthrosis staging and the time and type of postoperative immobilization. Besides, Merrel et al. ${ }^{17}$ believe that scaphoid consolidation alone is an insufficient parameter for determining the success rate of the surgical treatment. Therefore, the relevant question is not whether to treat it this injury, but the best method to do so.

Several years ago, Slade and Dodds ${ }^{18}$ classified scaphoid pseudoarthrosis into six grades, based on the width of the devitalized area of the pseudoarthrosis focus, circumstances complicating the healing process, and the need for additional structural or biological improvements. These authors established that internal fixation using minimally invasive techniques is sufficient and effective in fractures with delayed presentation, fibrous union and/or pseudoarthrosis with minimal sclerosis; however, this approach is contraindicated in more advanced stages, especially in case of bone stock loss and "humpback"-like flexion deformity. For these advanced stages, an open decortication with a Fisk-Fernández trapezoidal anterior wedge graft and stable internal fixation result in a cure rate of up to $90 \%{ }^{7,19}$

The lack of a classification system to identify the type of non-union to be treated explains the variability of outcomes in the literature and the treatment of heterogeneous pseudoarthrosis groups with the same surgical technique. Arthroscopic assistance for scaphoid pseudoarthrosis treatment has gained popularity in recent years due to its minimally invasive approach. The direct visualization of the pseudoarthrosis focus and/or defect and the vascular state of both scaphoid fragments, as well as the assessment of associated lesions, provides relevant information to identify the type of scaphoid pseudoarthrosis to be treated. This vital information provided by arthroscopy and findings from traditional evaluation studies (radiography, computed tomography [CT] and magnetic resonance imaging [MRI]) have motivated the authors (MC \& DF) to develop a new classification with therapeutic orientation, which is very useful to determine alternatives for non-union management (-Figure 1).

Based on the interesting concepts of $\mathrm{Qu}$ and Von Schroeder ${ }^{20}$ on the potential osteogenic capacity of cells from scaphoid pseudoarthrosis focus, which can be stimulated by various bone-inducing factors, the encouraging results from the increased vascularization provided by radial and ulnar metaphyseal decompression for Kienböck disease therapy reported by Illaramendi et al., ${ }^{21}$ and the advantages of minimal surgical trauma of percutaneous and arthroscopic techniques sparing vascularization and ligament attachments, we started the prospective treatment with arthroscopic assistance of scaphoid pseudoarthrosis with no bone graft [ATSPsWBG] even in advanced cases presenting humpback deformities for several years. Outcomes were evaluated to determine the limits to indicate this technique, considering consolidation as treatment success, and to determine its feasibility.

\section{Materials and Methods}

From May 2007 to December 2018, 84 scaphoid pseudoarthrosis cases treated by one of the authors (MC) by percutaneous fixation under arthroscopic assistance with no bone graft were evaluated prospectively. Data was collected from the electronic medical records database of Hospital Universitario Austral (Pectra ${ }^{\circledR}$ System) by specialists from the Upper Limb Surgery sector. This study was approved by the institutional academic committee [CIE \# 17-021]. Among these 84 patients, 69 were males and 15 were females. Their average age was 31.42 years old (range, 12 to 61 ). The right side was affected in 69 cases, whereas the left side was compromised in 15 cases. The dominant limb was affected in $77.5 \%$ of cases (65 patients). Mean time from injury to surgical intervention was 20.57 months (range, 3 to 108 months). In 66 patients, fracture occurred during sports practice (soccer, roller, tennis, polo, motocross, rugby, karting); in eight patients, fracture occurred during daily life or work activities (fall from ladder or own height), while 10 patients did not remember exactly the time of injury. Twenty-three fractures were initially treated with immobilization with a cast including fingers and the forearm for an average period of 6.3 weeks (range, 4 to 12 ); 17 of these fractures already were immobilized at the time of visit. Fifty-six patients never received any treatment, including 10 who did not know the exact day of the injury. Two patients also presented IV and I metacarpal fractures, respectively, and both complained of occasional wrist pain at maximum efforts. These patients were also 


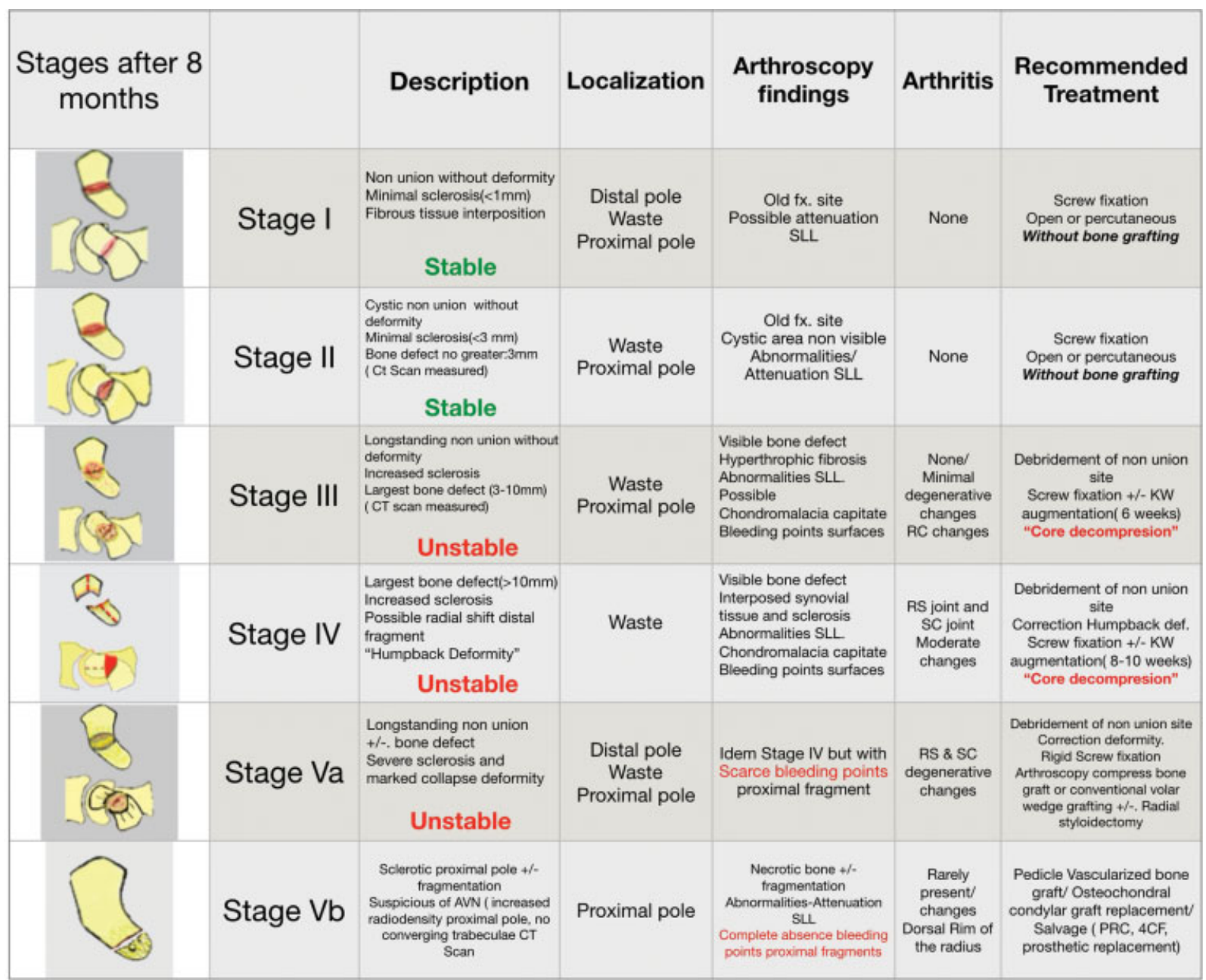

Figure 1 Proposed Classification of Scaphoid Pseudoarthrosis. Caloia M. \& Fernández D.

included in the study group and, simultaneously, the fracture was treated in an open procedure through internal fixation with a $2.3 \mathrm{~mm}$ plate, while scaphoid pseudoarthrosis was managed using the study technique. The remaining patients were deemed diagnostic errors and/or delayed visits. Six patients were smokers at the time of treatment ${ }^{22}$ and 19 patients occasionally took non-steroidal anti-inflammatory agents when local pain was exacerbated, often due to efforts and/or load transmission and radial deviation and extension. In this group, three patients had a degenerative wrist pattern predicting scaphoid nonunion advanced collapse (SNAC) grade I and II at the time of treatment ${ }^{23}$ ( 2 and 1 subject, respectively). The affected wrist from all patients was evaluated using the following studies:

a) Scaphoid-specific radiographic views: Frontal, posteroanterior (PA) view, simple lateral view, frontal PA with maximum ulnar deviation and oblique views in pronation and supination.

b) Axial computed tomography with helical reconstruction with 1-mm sagittal and coronal sections from the scaphoid axis to assess the degree of bone resorption, quantify cystic lesions, and determine the degree of collapse (if any), the thickness of the sclerotic edges of the pseudoarthrotic focus and the geometry of the proximal fragment. ${ }^{24,25}$

c) Simple magnetic resonance imaging (MRI): in cases of suspected avascular bone necrosis due to increased density in routine radiological evaluations or proximal/proximal pole pseudoarthrosis.

d) Wrist arthroscopy: in all cases, to define the pseudoarthrosis focus, the presence of hemorrhagic petechiae at both ends and concurrent cartilage and ligament injuries.

\section{Classification}

Based on test findings and previous concepts published by authors such as Herbert (1984), Alnot (1988) and Slade (2011), two of the authors (MC \& DF) proposed a new and detailed classification which was used to group the patients (-Figure 2). This classification defines non-union as lack of consolidation after 8 months, includes five types of nonunion and recommends the treatment for each stage.

Preoperative Assessment: Functional evaluation was performed systematically before surgery. Average range of motion was $53.5^{\circ}$ for extension (range, 46 to $89^{\circ}$ ), $55.7^{\circ}$ for flexion (range, 53 to $87^{\circ}$ ), $10.5^{\circ}$ for radial deviation (range, $5^{\circ}$ to $20^{\circ}$ ) and $20.8^{\circ}$ for ulnar deviation (range, $20^{\circ}$ to $36^{\circ}$ ). Hand 


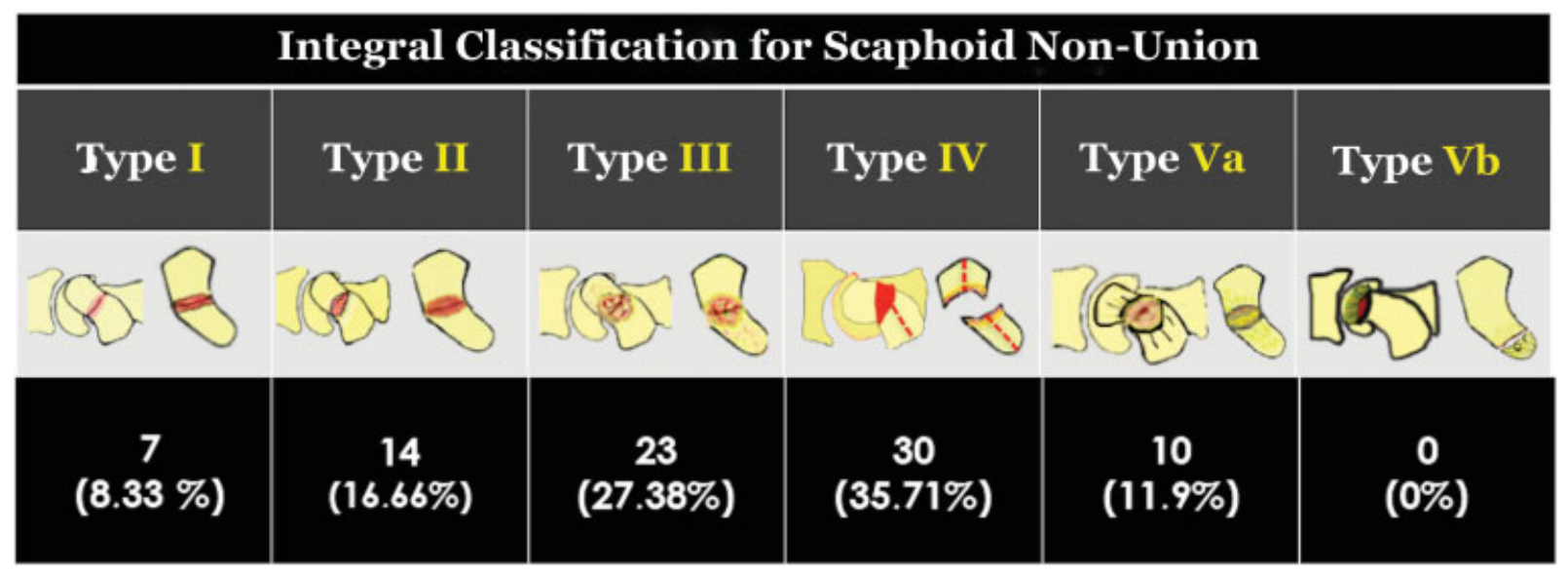

Figure 2 Number of Cases according the new classification.

grip measured with a Jamar® dynamometer (Sammons Preston, Bolingbrook, IL) was $68 \%$ compared to the contralateral side. Average score at VAS scale for pain was 4.8 (range, 3 to 6$)$.

\section{Surgical Technique}

The whole surgical procedure was performed under echoassisted regional anesthesia on an outpatient basis. A hemostatic cuff was used at $250 \mathrm{~mm} \mathrm{Hg}$ for soft limb compression to enhance hemorrhagic petechiae in more advanced cases. In cases of doubt regarding the viability of the proximal pole, bleeding from both fragments was assessed by arthroscopy soon after treatment of the pseudoarthrotic focus. Initially, wrist arthroscopy was performed for scaphoid pseudoarthrosis staging and to document concurrent injuries, including chondral articular cartilage lesion; primary emphasis was placed on the scapholunate ligament complex. Radiocarpal visualization often helps to determine the presence of associated lesions, and the assessment of lesions at the dorsal portion of the radial styloid cartilage, which is usually altered in cases of SNAC; midcarpal visualization allows the evaluation of the scaphoid ligament integrity and the determination of damage to the midcarpal joint cartilage and of the geometry of the proximal pole. Injuries found were classified and treated simultaneously according to previously published criteria. ${ }^{26}$ To do so, a Geissler-Slade (Acumed $\AA$, Beaverton, OR, USA) or Terry-Whiple (Conmed Linvantec ${ }^{\circledR}$ Corporation, Largo, FL) distraction tower with a 15-pound (4.5-5 kg) pull and an arthroscopic video device with 2.4$2.7 \mathrm{~mm}, 30^{\circ}$ optics (Karl Storz ${ }^{\circledR}$, Germany) were used. Arthroscopy was performed routinely using 3-4, 6R, radial midcarpal (MR), cubital midcarpal (MC) portals; a radial midcarpal accessory portal was used to assess the viability of the proximal pole and for curettage and/or milling were required. With the scope at the MC portal, the focus of pseudoarthrosis, the degree of scapholunate ligament involvement and capitate cartilage changes were assessed; however, main parameters included pseudoarthrosis focus features and the integrity of the cartilaginous scaphoid cover. In early stages (stages I to III), the non-union focus is observed as a cleavage line on the articular scaphoid surface with a stage-proportional fibrous interposition, corroborating the passage of the synovial fluid through the fracture focus as one of the pathognomonic causes for non-union, and obvious changes at the articular surface of the scaphoid cartilage. The firmness of the focus must be evaluated using a probe hook through the MCR portal; this stability often explains the lack of symptoms in some patients. In cases of focus fibrosis and/or mobility (stages IV), it is necessary to perform a debridement of the focus using a motorized synovium cutter with 2.0 - and $2.9-\mathrm{mm}$ burrs inserted at the same portal until the obtainment of a bleeding bed. After confirming the alignment, using an image intensifier, an antegrade osteosynthesis is performed. This procedure is done using the modified technique described by Slade et al. A mini dorsal approach avoids tendon damage; next, an \#16 catheter is used as a cannula to place the fine guide pin on the true scaphoid axis, trying to optimize its greater length and considering the shape of the proximal fragment at CT scans, mainly at proximal pseudoarthrosis, thus obtaining the greatest possible assembly rigidity. The image intensifier is used to obtain a "V" image ${ }^{27}$ from the proximal pole of the scaphoid in PA view with the wrist slightly flexed and ulnar deviation, locating the entry point at the vertex of the "V". With the pin placed in the "V" bisector, it is moved to a volar position and a new control is performed with wrist in semisupination and the forearm slightly raised to observe the socalled "golden line" in the middle third of the true scaphoid axis. ${ }^{28}$ These are crucial steps of the percutaneous technique. Next, the volar pin is passed to a dorsal position and an antirotation pin is placed parallel to the first one, allowing access to the cannulated reamer. Measurement and manual milling are performed according to the original technique, and osteosynthesis is done with a cannulated screw, preferentially a $3.5-\mathrm{mm}$ Acutrak mini (Acumed ${ }^{\circledR}$, Hillsbro, OR, USA) for presenting greater assembly rigidity. In more advanced stages, with greater pseudoarthrosis focus instability, collapse and humpback deformity (stages IV and some Va cases) and dorsal lunate deviation (DISI - major lunate angle $\geq 30^{\circ}$ ), a delicate curved, 3-mm curette and a motorized 2.0- and/or 2.9-mm synovium cutter were used to clean the focus, eliminating fibrous tissue, and improving focus surfaces 


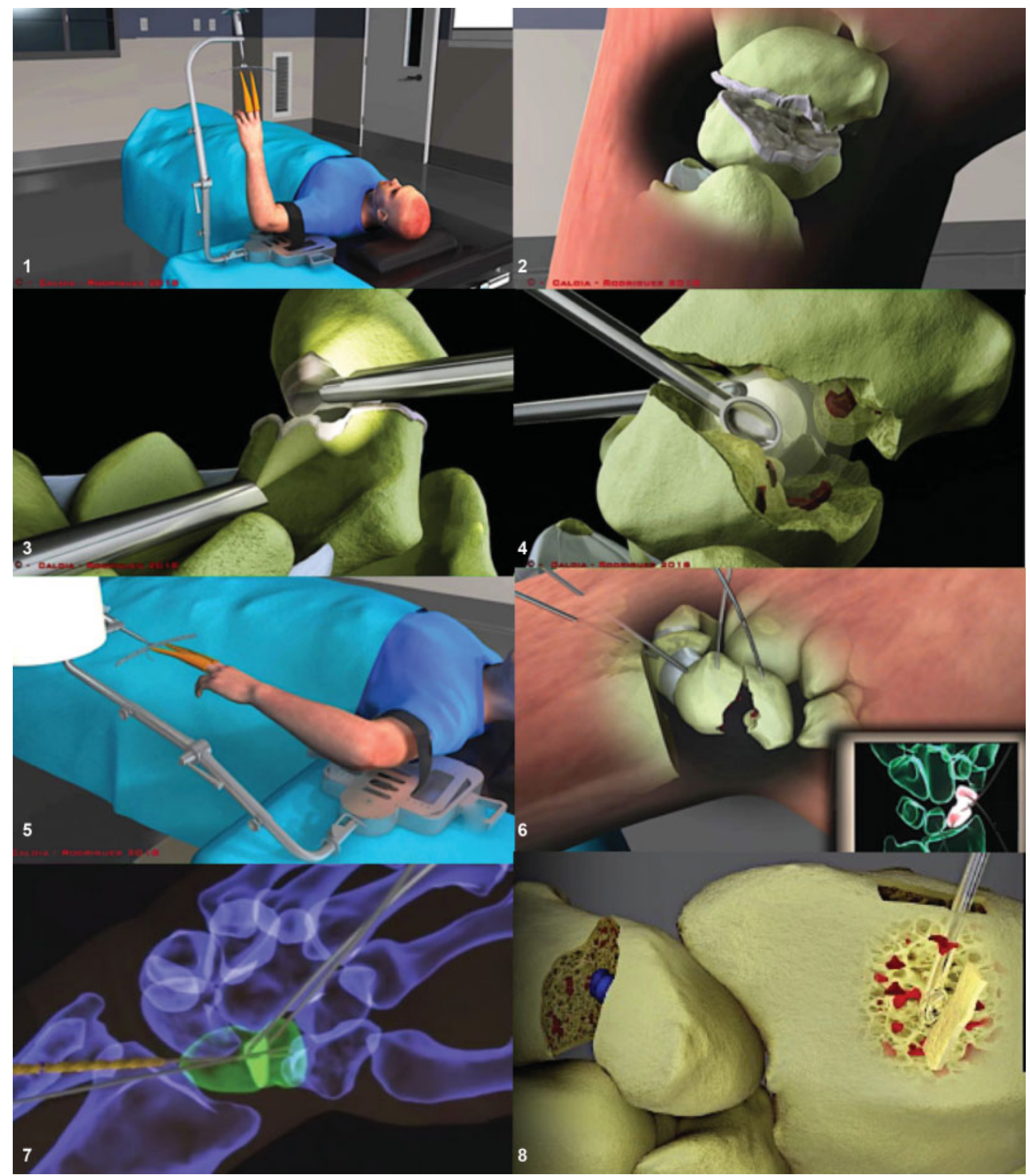

Diagram 1 Surgical Technique: [three-dimensional surgical technique sequence].

visualization and fragments mobility, which helps their reduction. If edges are sclerotic, previous perforations are made using Kirschner wires and a 2.9-mm burr until the observation of bleeding points at both ends; this arthroscopic sign is a fundamental requirement for the described technique. An MCR accessory portal or a scaphoid-trapezium-trapezoid (STT) portal may be useful for proximal fragment visualization. Deformity correction can be facilitated by the addition of the following measures: passive wrist flexion to restore the radiolunate angle, and temporary lunate fixation with a $1.0 \mathrm{~mm}$ Kirschner wire passed through the radio. Humpback deformity reduction is obtained after volar pin removal; extension, ulnar deviation and hypersupination allow scaphoid deflection and distal fragment reduction. The use of $1.0 \mathrm{~mm}$ Kirschner wires as "joysticks" is very helpful to reduce distal pseudoarthrosis with greater distal pole fragment instability. Since no bone graft was used, in cystic pseudoarthrosis with bone stock loss between 2 to 
$10 \mathrm{~mm}$ and/or collapse under flexion, a transient transfixing peg is placed for 6 to 8 weeks (as an adjuvant method to achieve greater stability of the pseudoarthrotic focus) from the scaphoid to the capitate for midcarpal joint immobilization; in very proximal pseudoarthrosis, a similar wire is added from the scaphoid to the lunate to improve scapholunate joint fixation. Subsequently, in these advanced stages, the procedure is completed with a metaphyseal decompression according to the Illarramendi et al. ${ }^{21}$ and modified by using the same route only at the distal radial epiphysis. (Diagram 1-surgical technique: key steps 1-8). Associated ligament injuries were treated simultaneously according to the Geissler et al. ${ }^{29}$ classification.

Postoperative Period: the patient is immobilized for 6 weeks with a cast including the thumb and forearm; next, a removable splint is used until consolidation. In this period, the patient is allowed to start performing mild, progressive flexion/extension exercises through a regular rehabilitation program; contact sport and/or strenuous activities are not allowed until consolidation. Patients were monitored with radiographic evaluations at the first, third and sixth week and then monthly until consolidation. Bone union is confirmed in all cases by CT scans and the patient is considered discharged when bone bridges are observed in $50 \%$ of the scaphoid in sagittal plane. The exact time for bone consolidation was not recorded.

All patients with advanced pseudoarthrosis stages (Stage Va) and grade IV with avascular proximal pole necrosis were submitted to a technetium 99 scintigraphy with pinhole single photon emission computerized tomography (SPECT) to determine the biological adjuvant effect of radius metaphyseal decompression. This study is based on the detection of radioisotopes and obtains early- and late-phase images to detect passage through soft tissues and bone uptake; it can be associated with a CT scan to provide better functional and anatomical information. Patients were followed-up for an average time of 52.34 months (range, 24 to 120 months). Finally, wrist global function was evaluated through the modified Mayo Clinic score. This score is a 0 to 100 -point scale, where 100 represents normal wrist function. It is based on pain (25 points), range of motion (25 points), grip strength (25 points) and functional status (25 points) ratings.

\section{Results}

According to the proposed classification, seven stage I (8.33\%), 14 stage II (16.66\%), 23 stage III (27.38\%), 30 stage IV (35.71\%) and 10 stage Va (11.9\%) patients were treated. There were no Grade Vb cases. In 25 cases, simple MRI revealed signal changes at the proximal pole of the scaphoid that were interpreted as necrosis, with the following distribution: five stage II, eight stage III, two stage IV and 10 stage Va cases. These findings were not correlated with pathological anatomy results. Axial CT scans showed displacement and flexion deformity in 44 cases. Arthroscopy revealed the existence of associated lesions with the following distribution: scapholunate ligament injury, Geissler grade I in 11 cases, grade II in 18 cases and III in 12 cases. Two patients presented a type ID triangular fibrocartilage complex injury, while four patients had a Palmer type IB lesion; all cases were treated with debridement. ${ }^{30}$ Fourteen patients had a pattern of constant chondral capitate injury at the midcarpal joint level, on the articular face with the scaphoid bone; these lesions were classified as grade III ( 8 cases) and IV ( 6 cases) according to Outerbrigde. Self-compressing cannulated screws with Acutrak (Acumed ${ }^{\circledR}$, Hillsbro, OR, USA) (59 mini, 15 standard and 6 micro screws) were used in 79 patients; five patients received double-threaded self-compressing cannulated screws (Twin Fix ${ }^{\circledR}$ Stryker and New Clips $\left.{ }^{\circledR}\right)$. The average follow-up period was 52.34 months (range, 24 to 120 months). Pseudoarthrosis consolidation, documented by CT scans, occurred in 77 (91.66\%) patients. In cystic pseudoarthrosis, the bone defect was filled with new bone growth, even when the cyst exceeded $10 \mathrm{~mm}$. The visual analog scale showed an average postoperative pain of 1.04 point (range, 0 to 2 points). On average, postoperative functional range was $65.3^{\circ}$ for extension (range, 46 to $88^{\circ}$ ), $69.2^{\circ}$ for flexion (range, 55 to $88^{\circ}$ ), $10.7^{\circ}$ for radial deviation (range, 5 to $20^{\circ}$ ) and $26^{\circ}$ for ulnar deviation (range, 20 to $37^{\circ}$ ). On average, the Mayo Clinic score was $95 \pm 6$.

Seven patients (8.33\%) did not present bone consolidation 9 months after the procedure and four patients required a new surgery. Among them, only one patient had mild effortrelated discomfort and the reoperation was decided due to imaging findings. All of these patients presented non-union of the scaphoid body, including two cases in stage IV and two cases in stage Va. Of these four patients, two had a history of smoking; in two cases, the pseudoarthrosis was long-standing (60 and 108 months, respectively) and characterized by prominent sclerotic edges at CT scans. In one of them (stage Va), hemorrhagic petechiae were not obvious; in the other patient, the screw was inadequately positioned, not coinciding with the central scaphoid axis and outside the geometric arrangement of the proximal pseudoarthrotic fragment. Reoperation was performed using a minimally invasive technique similar to the one previously described, but with the percutaneous addition of a cancellous bone graft from the distal radius to the focus using a trephine ${ }^{31}$ under arthroscopic assistance. A new cannulated screw was placed and a transient pin from the distal scaphoid pole to the midcarpal joint was used for 6 to 8 weeks to increase assembly rigidity. The procedure was successful in both patients (Clinical Case: - Figure 3 A-F).

\section{Discussion}

Scaphoid fracture management remains an unsolved problem, representing a major economic impact ${ }^{32}$ and a nonconsolidation rate from 10 to $13 \%$ of all cases. ${ }^{33,34}$ The carpal scaphoid bone is difficult to treat and has intrigued several generations of hand surgeons. ${ }^{35}$ Its shape, alignment and small size difficult evaluation using through imaging studies. Symptomatic pseudoarthrosis has been classically treated with internal fixation plus autologous bone graft. However, bone consolidation is not assured, especially in smokers. ${ }^{22-36}$ 
In the initial stages of scaphoid pseudoarthrosis without substantial bone resorption, no appreciable collapse of the scaphoid architecture and no subjective signs of proximal pole necrosis (stages I-II), minimally invasive surgery offers predictable and encouraging outcomes and high consolidation rates without requiring a bone graft, which is associated with technical difficulty, prolonged surgical time and higher morbidity. The fibrous union of scaphoid fractures (stage I) is due to the interruption of the healing process in its early stages, in addition to micro-movements and the lack of focal mechanical stability. ${ }^{37}$ Focus stabilization allows the process to continue, leading to consolidation. Pseudoarthrosis with minimal sclerosis (stages II-III) is similar to fibrous union, requiring compression and rigid fixation alone for healing. Cosio and Camp ${ }^{38}$ demonstrated that pseudoarthrosis stabilization with multiple Kirschner wires resulted in solid consolidation in $77 \%$ of the cases without open repair or bone grafting. Outcomes from the technique proposed for advanced grades (stages I-II-III) are similar to those recently reported by other authors. ${ }^{23,39-44}$ Elegant in vitro studies from Qu and Von Schroeder ${ }^{20}$ have determined that cells from the non-binding surface site and from the scaphoid cartilage zone with more than a decade of evolution can be re-stimulated with bone morphogenic protein 2 (BMP2) to develop functional osteoblasts that can generate bone tissue and contribute to healing. This concept inspired the author $(\mathrm{MC})^{42}$ to consider that cells from the pseudoarthrotic focus can be stimulated by factors that promote cell differentiation and the required osteogenesis which, along with the internal compression and stabilizing fixation of the focus, would favor consolidation. In addition, the biological effects generated by certain techniques that cause radial injury, such as the contributions from Illarramendi et al. ${ }^{21}$ on radial metaphyseal decompression for lunate avascular necrosis treatment, and from Monreal, ${ }^{45}$ who performed closure osteotomies of the distal radius for scaphoid pseudoarthrosis treatment as adjuvants, to extend the technical indication to more advanced stages with large bone defects and/or flexural collapse (stage III, IV Va). A constant pattern of increased vascular perfusion of the entire radial spine was recorded by SPECT. Since this behavior of the body in response to radial metaphyseal aggression would increase regional vascularization, ${ }^{42,46}$ the author conjectures that the benefit was not only related with the vascular supply, but also the release of several unidentified growth factors that stimulate the osteoblastic differentiation of cells from the pseudo-osteoarthritic focus, favoring the osteogenesis required for consolidation.

Open procedures can affect the limited vascular supply of the scaphoid ${ }^{47}$ and damage the radiocarpal palmar ligaments of the wrist, ${ }^{48}$ resulting in loss of correct carpal alignment. On the other hand, compared to the open exposure that provides limited vision, arthroscopy offers a better detailed evaluation of the scaphoid and allows determining the type of pseudoarthrosis as stable or unstable, its vascular status and the quality of the reduction. Based on these outcomes $^{42,49}$ and other publications, ${ }^{28,50,51}$ the author can conclude that lesion age, internal fixation stability and hemorrhagic petechiae observed during surgery are determining factors for consolidation, regardless of the scaphoid gap or flexion deformity for technique indication. Therefore, there is a large number of advanced stage scaphoid nonunions that do not require bone grafting for consolidation.

It can also be concluded that the imaging studies commonly used for preoperative evaluation are not predictive of the type of pseudoarthrosis to be treated; here, arthroscopy plays a relevant diagnostic role in staging, allowing the surgeon to choose the best option. In such cases, arthroscopic assistance has the following additional potential advantages:

a) Magnified evaluation of the vitality of both scaphoid fragments

b) Diagnosis and treatment of concurrent injuries, such as scapholunate ligament lesions, possibly explaining why certain fractures present greater focal micro-mobility and evolve into pseudoarthrosis $(14.28 \%$ of patients with scapholunate ligament injuries, Geissler grade III).

c) Determine the fixation stability, especially in those advanced cases with significant bone defects and thus ascertain whether an increased assembly fixation is required; such fixation is performed with a transient Kirchner wire from the distal pole of the scaphoid to the capitate or lunate bone, depending on the topography of the scaphoid defect.

d) Explain the development of post-consolidation wrist pain, which often results from osteochondral injuries in the capitate bone, especially in advanced stages of the condition.

e) Precise evaluation of the non-union focus reduction and/or,

f) Correct implant placement, in a biological environment favoring consolidation, with minimal surgical trauma to ligament architecture of and/or poor scaphoid vascularization.

We (MC \& DF) believe that the proposed classification offers a rational and complete approach based on the patient's history, pathological state and information provided by imaging studies and arthroscopy to finally define the treatment.

On the other hand, it is important to highlight that this work has weaknesses: the sample size, exact time for consolidation, lack of randomization and/or comparison with a control group, no identification of true osteogenic factors or modulators acting at the pseudoarthrosis focus, and the recognition that the technique requires appropriate surgical skills. However, the originality in such a controversial topic and outcomes from some recent publications ${ }^{42,44,46,51}$ originate potential research lines. The highly encouraging results and the benefits from minimally invasive surgery and arthroscopic assistance are technical strengths; nevertheless, this does not invalidate the use of other required techniques in case of failure, complying with the "do not burn bridges" aphorism.

\section{Conclusion}

Based on the success rate of this series, the arthroscopic treatment of scaphoid pseudoarthrosis without bone graft is recommended as a feasible therapeutic approach for young or middle-aged, non-smoking patients with no history of wrist surgeries and lack of scaphoid consolidation. A 

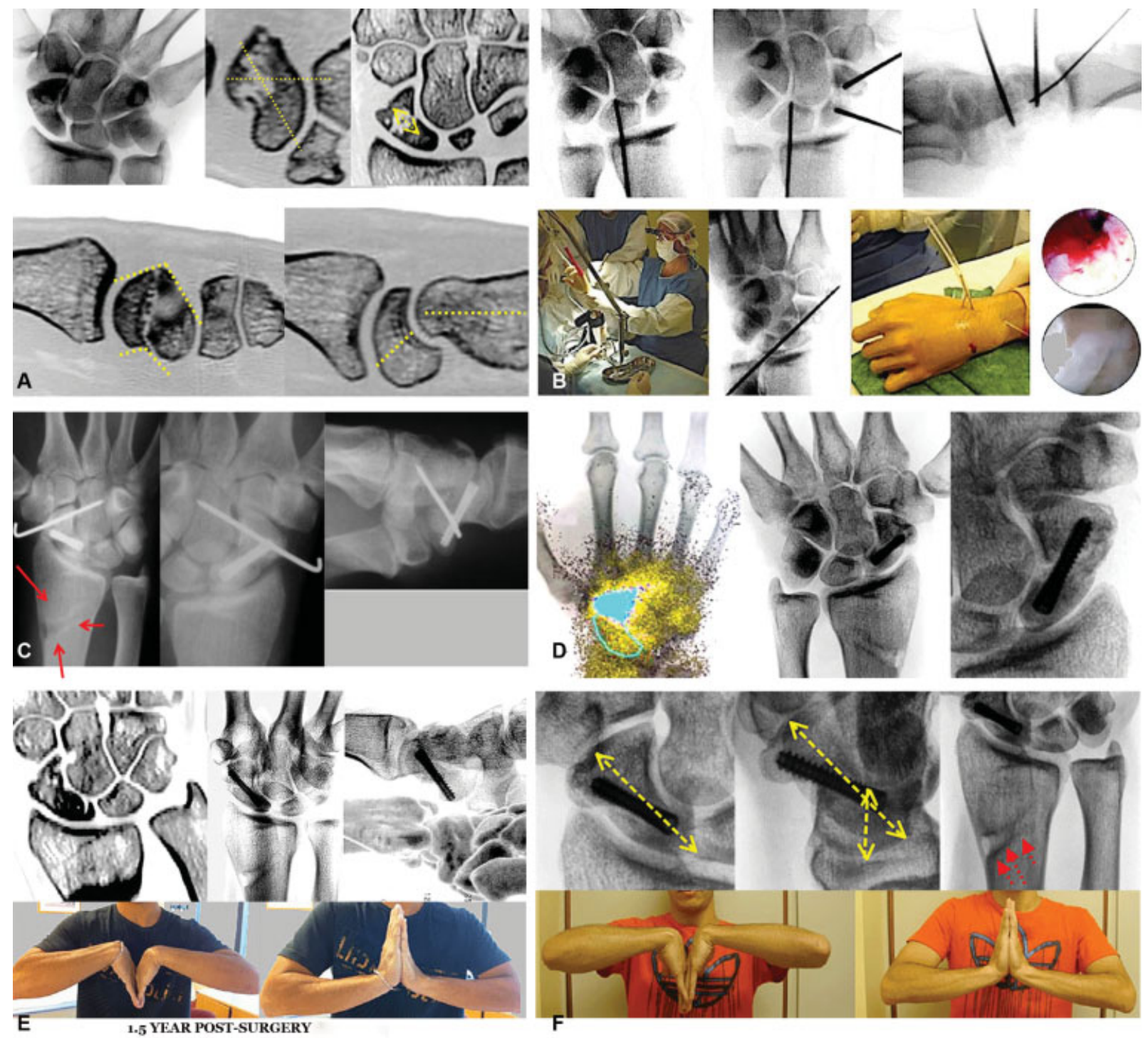

Fig. 3 (A) Male, 25-year-old patient with pseudoarthrosis of the right scaphoid body for 3 years, in stage IV of the proposed classification: resorption and flexion deformity with carpal misalignment. (B) Surgical Sequence: Arthroscopic treatment of the pseudoarthrotic focus, with intervening synovial and fibrous tissue release followed by dorsal lunate deviation and scaphoid humpback-like deformity correction. Arthroscopic Findings: capitate cartilage injury, Outerbridge grade IV. There was bleeding from the proximal pole after hemostatic cuff release. (C) Eight weeks after surgery. Wrist single photon emission computerized tomography (SPECT): Increased vascular and tissue perfusion at the distal radius, scaphoid, trapezius and trapezoid bones. Radiological follow-up reveals consolidation and bone regeneration signs at gap level. (D) Radiological and tomographic follow-up at 1.5 year after surgery. Posteroanterior (PA) and lateral radiographs and a sagittal computed tomography scan show alignment preservation and defect filling with bone regeneration. Functional range of motion in flexion-extension. (E) Radiological follow-up at 4 years after surgery. PA and lateral radiographs show maintenance of carpal scaphoid alignment and length. Signs of metaphyseal decompression. (F) Functional range of motion at 7 years.

previous CT scan must exclude the presence of excessive sclerosis, a very small proximal fragment or an inadequate bone tissue for screw to ensures stable internal fixation; in addition, the absence and/or scarcity of focal hemorrhagic petechiae must be excluded by an arthroscopic evaluation. Metaphyseal decompression of the distal radius produces a constant hypervascularization response in the radial column of the wrist.

\section{Conflict of Interest}

The authors declare no conflicts of interest.

\section{Acknowledgements}

I would like to thank Dr. Juan Andrés Pinzón, fellow at the Superior Member Surgery team from Hospital Austral, for his collaboration in evaluating medical records, and Prof. Dr. Diego L. Fernández for his teachings, which stimulated me to search for new techniques to treat a condition as challenging as the carpal scaphoid pseudoarthrosis.

\section{References}

1 Hackney LA, Dodds SD. Assessment of scaphoid fracture healing. Curr Rev Musculoskelet Med 2011;4(01):16-22 
2 Hove LM. Epidemiology of scaphoid fractures in Bergen, Norway. Scand J Plast Reconstr Surg Hand Surg 1999;33(04):423-426

3 Bond CD, Shin AY, McBride MT, Dao KD. Percutaneous screw fixation or cast immobilization for nondisplaced scaphoid fractures. J Bone Joint Surg Am 2001;83(04):483-488

4 Cooney WP, Dobyns JH, Linscheid RL. Fractures of the scaphoid: a rational approach to management. Clin Orthop Relat Res 1980; (149):90-97

5 Szabo RM, Manske D. Displaced fractures of the scaphoid. Clin Orthop Relat Res 1988;(230):30-38

6 Taleisnik J, Kelly PJ. The extraosseous and intraosseous blood supply of the scaphoid bone. J Bone Joint Surg Am 1966;48(06): 1125-1137

7 Eggli S, Fernandez DL, Beck T. Unstable scaphoid fracture nonunion: a medium-term study of anterior wedge grafting procedures. J Hand Surg [Br] 2002;27(01):36-41

8 Herbert TJ, Fisher WE. Management of the fractured scaphoid using a new bone screw. J Bone Joint Surg Br 1984;66(01):114-123

9 Gelberman RH, Menon J. The vascularity of the scaphoid bone. J Hand Surg Am 1980;5(05):508-513

10 Jupiter JB, Shin AY, Trumble TE, Fernandez DL. Traumatic and reconstructive problems of the scaphoid. Instr Course Lect 2001; 50:105-122

11 Berger RA. The anatomy of the scaphoid. Hand Clin 2001;17(04): 525-532

12 Schuind F, Haentjens P, Van Innis F, Vander Maren C, Garcia-Elias M, Sennwald G. Prognostic factors in the treatment of carpal scaphoid nonunions. J Hand Surg Am 1999;24(04):761-776

13 Inoue G, Shionoya K, Kuwahata Y. Herbert screw fixation for scaphoid nonunions. An analysis of factors influencing outcome. Clin Orthop Relat Res 1997;(343):99-106

14 Berger RA, Crowninshield RD, Flatt AE. The three-dimensional rotational behaviors of the carpal bones. Clin Orthop Relat Res 1982;(167):303-310

15 Short WH, Werner FW, Fortino MD, Mann KA. Analysis of the kinematics of the scaphoid and lunate in the intact wrist joint. Hand Clin 1997;13(01):93-108

16 Barton NJ. Experience with scaphoid grafting. J Hand Surg [Br] 1997;22(02):153-160

17 Merrell GA, Wolfe SW, Slade JF III. Treatment of scaphoid nonunions: quantitative meta-analysis of the literature. J Hand Surg Am 2002;27(04):685-691

18 Slade JF III, Dodds SD. Minimally invasive management of scaphoid nonunions. Clin Orthop Relat Res 2006;445(445):108-119

19 Fernández DL. Anterior bone grafting and conventional lag screw fixation to treat scaphoid nonunions. J Hand Surg Am 1990;15 (01):140-147

20 Qu G, von Schroeder HP. The osteogenic potential of pseudoarthrosis tissue and bone from human scaphoid non-unions. J Hand Surg Eur Vol 2008;33(04):449-456

21 Illarramendi AA, Schulz C, De Carli P. The surgical treatment of Kienböck's disease by radius and ulna metaphyseal core decompression. J Hand Surg Am 2001;26(02):252-260

22 Little CP, Burston BJ, Hopkinson-Woolley J, Burge P. Failure of surgery for scaphoid non-union is associated with smoking. J Hand Surg [Br] 2006;31(03):252-255

23 Vender MI, Watson HK, Wiener BD, Black DM. Degenerative change in symptomatic scaphoid nonunion. J Hand Surg Am 1987;12(04):514-519

24 Bain GI, Bennett JD, Richards RS, Slethaug GP, Roth JH. Longitudinal computed tomography of the scaphoid: a new technique. Skeletal Radiol 1995;24(04):271-273

25 Sanders WE. Evaluation of the humpback scaphoid by computed tomography in the longitudinal axial plane of the scaphoid. J Hand Surg Am 1988;13(02):182-187

26 Caloia MF, Gallino RN, Caloia H, Rivarola H. Incidence of ligamentous and other injuries associated with scaphoid fractures during arthroscopically assisted reduction and percutaneous fixation. Arthroscopy 2008;24(07):754-759

27 Caloia M La mano y muñeca del deportista de alto y bajo rendimiento" tema fractura de escafoides, Comunicación Oral $47^{\circ}$ Congreso Argentino de Ortopedia y Traumatología, Bs. As., Diciembre 2010

28 Wong WY, Ho PC. Minimal invasive management of scaphoid fractures: from fresh to nonunion. Hand Clin 2011;27(03): 291-307

29 Geissler WB, Freeland AE, Savoie FH, McIntyre LW, Whipple TL. Intracarpal soft-tissue lesions associated with an intra-articular fracture of the distal end of the radius. J Bone Joint Surg Am 1996; 78(03):357-365

30 Palmer AK. Triangular fibrocartilage disorders: injury patterns and treatment. Arthroscopy 1990;6(02):125-132

31 Slade JF III, Gillon T. Retrospective review of 234 scaphoid fractures and nonunions treated with arthroscopy for union and complications. Scand J Surg 2008;97(04):280-289

32 Buijze GA, Jørgsholm P, Thomsen NO, Bjorkman A, Besjakov J, Ring D. Diagnostic performance of radiographs and computed tomography for displacement and instability of acute scaphoid waist fractures. J Bone Joint Surg Am 2012;94(21):1967-1974

33 Dias JJ, Brenkel IJ, Finlay DB. Patterns of union in fractures of the waist of the scaphoid. J Bone Joint Surg Br 1989;71(02):307-310

34 Düppe H, Johnell O, Lundborg G, Karlsson M, Redlund-Johnell I. Long-term results of fracture of the scaphoid. A follow-up study of more than thirty years. J Bone Joint Surg Am 1994;76(02): 249-252

35 Dias JJ. Definition of union after acute fracture and surgery for fracture nonunion of the scaphoid. J Hand Surg [Br] 2001;26(04): 321-325

36 Dinah AF, Vickers RH. Smoking increases failure rate of operation for established non-union of the scaphoid bone. Int Orthop 2007; 31(04):503-505

37 Haddad FS, Goddard NJ. Acute percutaneous scaphoid fixation. A pilot study. J Bone Joint Surg Br 1998;80(01):95-99

38 Cosio MQ Camp RA. Percutaneous pinning of symptomatic scaphoid nonunions. J Hand Surg Am 1986;11(03):350-355

39 Merrell G, Slade J. Technique for percutaneous fixation of displaced and nondisplaced acute scaphoid fractures and select nonunions. J Hand Surg Am 2008;33(06):966-973

40 Shah J, Jones WA. Factors affecting the outcome in 50 cases of scaphoid nonunion treated with Herbert screw fixation. J Hand Surg [Br] 1998;23(05):680-685

41 Wozasek GE, Moser KD. Percutaneous screw fixation for fractures of the scaphoid. J Bone Joint Surg Br 1991;73(01):138-142

42 Martín F Caloia, Hugo F. Caloia, Diego González Scotti, Diego L. Fernández. Arthroscopic Treatment of Scaphoid Nonunion without Bone Graft and Distal Radius Decompression. Hand 2016. Volume: 11 issue: 1_suppl, page(s): 111S-112S. Article first published online: September 26, 2016

43 Dedeoğlu SS, İmren Y, Çabuk H, Tekin AC, Türe YC, Gürbüz H. Results of percutaneous fixation and distal radius core decompression in scaphoid waist non-unions treated without grafting. Hand Surg Rehabil 2018;37(01):43-47

44 Liu B, Wu F, Ng CY. Wrist arthroscopy for the treatment of scaphoid delayed or nonunions and judging the need for bone grafting. J Hand Surg Eur Vol 2019;44(06):594-599. Doi: $10.1177 / 1753193419841253$

45 Monreal R. Treatment of scaphoid nonunions with closed-wedge osteotomy of the distal radius: Report of six cases. Hand (N Y) 2008;3(02):91-95

46 Rellan I, Gallucci GL, Boretto JG, Donndorff AG, Zaidenberg EE, De Carli P. Metaphyseal Core Decompression and Anterograde Fixation for Scaphoid Proximal Pole Fracture Nonunion without Avascular Necrosis. J Wrist Surg 2019;8(05):416-422. Doi: $10.1055 / \mathrm{s}-0039-1692472$ 
47 Botte MJ, Mortensen WW, Gelberman RH, Rhoades CE, Gellman H. Internal vascularity of the scaphoid in cadavers after insertion of the Herbert screw. J Hand Surg Am 1988;13(02):216-220

48 Garcia-Elias M, Vall A, Salo JM, Lluch AL. Carpal alignment after different surgical approaches to the scaphoid: a comparative study. J Hand Surg Am 1988;13(04):604-612

49 Oral Communications during XX FEESH Congress - EWAS Session A-0742 - Arthroscopic Management of Scaphoid Nonunion without Bone Graft - Martín F. Caloia (Argentina). Milan, Italy 17-20 June 2015
50 Joseph F. Slade III; Andrew P. Gutow, William B. Geissler, Percutaneous Internal Fixation of Scaphoid Fractures via an Arthroscopically Assisted Dorsal Approach J Bone Joint Surg. Am 2002;84: S21-S36

51 Mahmoud M, Koptan W. Percutaneous screw fixation without bone grafting for established scaphoid nonunion with substantial bone loss. J Bone Joint Surg Br 2011;93(07):932-9366

52 Taleisnik J, Kelly PJ. The extraosseous and intraosseous blood supply of the scaphoid bone. J Bone Joint Surg Am 1966;48(06): 1125-1137 